FACTA UNIVERSITATIS

Series:Economics and Organization Vol. 16, N ${ }^{\circ} 4,2019$, pp. 389- 401

https://doi.org/10.22190/FUEO1904389D

Original Scientific Paper

\title{
SIGNIFICANCE OF INNOVATION FOR SUSTAINABLE ECONOMIC AND AGRICULTURAL DEVELOPMENT IN THE REPUBLIC OF SERBIA
}

\author{
UDC 502.131.1:330.34]:330.341.1(497.11) \\ 502.131.1:338.43]:330.341.1(497.11)
}

\begin{abstract}
Danijela Despotović, Lela Ristić, Miloš Dimitrijević
University of Kragujevac, Faculty of Economics, Kragujevac, Republic of Serbia
\end{abstract}

\begin{abstract}
Since it is not enough just to achieve economic development, we should strive for sustainable development over a longer period and base it on innovation. It is an extremely important factor of economic and sustainable development. It is particularly important to innovate those economic activities that are crucial for sustainable development and where there are comparative advantages. Because of that, the aim of this paper is to prove that innovation is the key to success and achieving sustainable development. The cluster analysis has highlighted innovative leaders and learners. The Republic of Serbia is a country where agriculture is one of the most important economic activities. In terms of agricultural productivity, it not only lags behind innovative leaders, but also behind other countries of Southeast Europe, distinguished as innovative learners. In addition, in terms of innovation in agriculture, it significantly lags behind other economic activities at the national level, so that special attention should be paid to this issue.
\end{abstract}

Key words: innovation, productivity, sustainable development, economic development, agriculture.

JEL Classification: 011, 013, 031, Q01

\section{INTRODUCTION}

In the modern world, it is very difficult to find a unique pattern of progress and the survival of a certain acceptable state for a longer period. That is why this is the time of new ideas, innovations and constant changes.

Received August 19, 2019 / Revised October 04, 2019 / Accepted October 07, 2019

Corresponding author: Miloš Dimitrijević

University of Kragujevac, Faculty of Economics, Liceja Kneževnine Srbije 3, 34000 Kragujevac, Serbia

E-mail: mdimitrijevic@kg.ac.rs 
Innovation, together with the knowledge that enables it, is an important factor in increasing competitiveness (Dajić, 2017). Innovation is the key for economic development and increasing employment, which means that this is a very important determinant of sustainable economic development (Despotović et al., 2014).

It is not enough to achieve only economic development, but it is necessary for this development to be sustainable over a longer period, with respect to the ecological and social component. Because sustainable development is a multidimensional concept that relies on all three pillars (Giddings et al., 2002): economic, environmental and social.

Historically, the concept of sustainable development has emerged in the context of environmental problems. Interaction of investments in industrialization and agricultural production, exhaustion of natural resources, increase in the population are just some of the elements that are analyzed and based on which proposals are given for mitigation and solving of environmental problems (Miltojević, 2011, p. 641).

In accordance with the previously mentioned concept of sustainable development, the subject of research in this paper is the relationship between innovation and sustainable development in more economically developed and innovative countries (Germany, USA, Switzerland, Taiwan, Sweden, Japan, UK, Korea, Netherlands, Finland) and countries of Southeast Europe (Slovenia, Croatia, Greece, Romania, Bulgaria, Montenegro, Albania, Bosnia and Herzegovina, Serbia, North Macedonia), with a special accent on Serbia.

The aim of the paper is to prove that new ideas and innovations are necessary for a sustainable development of the economy and agriculture, which can be born only with greater investment and dedication to science, research and development.

Based on the subject and aim of the research, a hypothetical framework is defined:

$\mathrm{X}_{1}$ : Innovative countries are developing more rapidly.

$\mathrm{X}_{2}$ : Innovation is a very important factor for the future development of agriculture in the Republic of Serbia.

\section{LITERATURE REVIEW}

In addition to research and development (R\&D), the growth and innovation capacity of the economy depends on the ability to absorb technology and the demand for its production and use (Radošević, 2004, p. 646). Innovative activities include internal and external R\&D, capital expenditure, human resources development, market design and development, etc. (Gault, 2018, p. 618).

The most innovative countries are considered innovative leaders, while the least innovative are innovative learners. Despotović et al. (2016) indicate that the most innovative economies are mainly economically developed countries.

In the innovation segment, the Republic of Serbia should further encourage the development of patents, improve the quality of scientific and research institutions, and at the same time eliminate weaknesses in the connection between science and the economy (Savić et al., 2015, p. 74).

The competitiveness of a nation depends on the ability of its economy to innovate and improve (Porter, 2008, p. 159). This is particularly important if it positively reflects the dimensions of sustainable development, which could best be seen if sustainable development indicators are considered, such as Human Development Index (HDI) and Ecological Footprint vs Biocapacity per person (Moran et al., 2008). The ecological footprint should be less than 
bioaccumulation. Since this has not been the case in Serbia for years, then there is an ecological deficit (Global Footprint Network, 2018). It is important to point out that HDI (UNDP, 2005) is used as an indicator of sustainable development, and Ecological footprint (Wackernagel et al., 2002; Wackernagel et al., 2005) as an indicator of sustainable consumption. As a minimum, sustainability requires the avoidance of a global overdraft, or the relationship of the Ecological relationship to bioaccumulation greater than 1, thus $\leq 1$ is a necessary condition for sustainability (Ceballos et al., 2005).

Although the significance of GDP is inseparable in economic publications, composite indexes that integrate multiple indicators, such as HDI, the Global Competitiveness Index and others, are increasingly used (Gligorić et al., 2018, p. 1254). Legatum Institute Prosperity Index (LPI) is a relatively newer and more comprehensive indicator that uniquely describes the level and dynamics of prosperity in countries around the world (Gligorić et al., 2018), according to which Serbia is $56^{\text {th }}$ (Legatum Institute, 2018).

Serbia needs to adapt the development strategy to the new development and technological paradigm in order to establish an innovative environment (Bošnjak, 2005a, p. 33). A key element for establishing a more functional interaction between the R\&D institutions and the economy is the establishment of a balanced program of long-term technological development that will be complementary to strategic development priorities, especially in the context of integration processes in the European Union (Jakopin, 2011, p. 85). In addition, the acceptance of the new concept of creating and maintaining competitive advantages based on scientific knowledge and technological development is necessary (Bošnjak, 2005b, p. 131).

As the most important analytical framework for expressing the achieved level of economy innovation is using the Global Innovation Index (GII) and the $12^{\text {th }}$ pillar of the Global Competitiveness Index (GCI) (Despotović et al., 2014). In the research of innovation activities, the elements of the $12^{\text {th }}$ Pillar of the GCI are used (Innovation as an innovation indicator): Capacity for innovation, Quality of scientific-research institutions, $R \& D$ costs of the company, University-industry cooperation in R\&D, Government procurement of advanced technology products, Availability of scientists and engineers per million population (World Economic Forum, 2013, p. 51; Krstić et al., 2019, p. 20).

Innovation is considered the main driver of growth. The global median of the pillar Innovative Capabilities is 36 (out of 100), which is by far the lowest score in $12^{\text {th }}$ pillars of GCI. In 77 countries of 140 Innovation is the weakest pillar. The results show that there are only a few innovation forces in the world, i.e. super innovators whose score is above 80: Germany, USA, Switzerland and Taiwan (China) (Schwab, 2018, p. 7). According to an innovative system based on business sophistication and innovative capability, Europe and North America are predominant (Schwab, 2018, p. 25).

Of the 140 analyzed countries according to the latest Report of the World Economic Forum in 2018, and to the $12^{\text {th }}$ pillar of the GCI, innovation leading countries are: Germany (87.5), USA (86.5), Switzerland (82.1), Taiwan (China) (80.8), Sweden (79.8), Japan (79.3), UK (79.2), Korea (78.2), Netherlands (77.5) 76.3), France (76.1), Denmark (75.4), Canada (75), Singapore (75), Austria (74.3); while at the bottom of the rankings are: Angola (16.8), Congo (18.8), Haiti (20.3) Cape Verde (21.4), Chad (21.6), Liberia (22), Eswatini (22.7), Yemen (22.8), Lesotho (23.7), Burkina Faso (24.9), Zimbabwe (25.5), Mauritania (25.5), Ethiopia (26.5), Benin (26.7), Kyrgyz Republic (26.7). The change in relation to the previous report came for Serbia. It recorded growth in terms of innovation and is now $56^{\text {th }}$ (39.7) (Schwab, 2018). 
According to the latest Report GII 2018, Switzerland ranks first, followed by the Netherlands, Sweden, UK, Singapore, USA, Finland, Denmark, Germany, Ireland (WIPO, 2018a, p. 17). The economies which realize at least $10 \%$ above the average GDP of other countries are called innovators - achieve innovation (WIPO, 2018a, p. 34). In 2018, among the innovators according to this criterion, Serbia was included (WIPO, 2018a, p. 35). Serbia occupies $57^{\text {th }}$ position according to the global Innovation Efficiency Ratio (which is a progress from the $67^{\text {th }}$ position in 2017 and from $70^{\text {th }}$ place in 2016), which is $11^{\text {th }}$ place among 34 countries with upper-middle income. Serbia is in the ranking of 39 countries in Europe on the $35^{\text {th }}$ place. Compared with the countries of Europe, Serbia is below the average according to the GII (WIPO, 2018b). Therefore, Serbia is a moderate innovator (European Commision, 2018).

From the point of view of innovation, it is important to point out that one country's economic policy should be based on the comparative advantages of the country. It is visible that agriculture and food industry in Serbia are very important in that context (Ančić et al., 2014 , p. 306). Accordingly, a strategic commitment is needed to make agriculture one of the important economic sectors based on knowledge and innovation (Ristić, 2016), in order to transform the comparative advantages of agriculture into competitive ones. Creativity and innovation are considered new approaches in the field of rural and agribusiness development (Kvrgić \& Ristić, 2018, p. 35).

Modern agriculture becomes the area of information technology use (Praća et al., 2017 , p. 43). At the same time, sustainable agriculture is based on the use of technologies that maximize productivity and minimize negative effects on natural resources (land, water and biodiversity) and human resources (rural population and consumers) (Praća et al, 2017, p. 44). The key questions in the field of innovation are why and when it appears, as well as by whom it is initiated. The need for change is an essential component, as well as population growth and environmental change (Van der Veen, 2010, p. 5), which makes innovation in agriculture different from other sectors, with the fact that the production of sufficient quantity of quality of food appears as an extremely important global issue.

\section{EMPIRICAL RESEARCH}

\subsection{Research Methodology}

The Statistical program SPSS was used for processing and analysis of collected data. The collected data were analyzed in two levels.

The first level of analysis is the cluster of analyzes of selected countries for the period 2007-2017. For the selection of the innovation indicators, the GCI is used which is divided into 12 pillars, arranged in three subindices. For the innovation of the economy, the most significant are the $11^{\text {th }}$ and $12^{\text {th }}$ pillar (innovation and business sophistication) as the pillars of the third subindex (innovation and sophistication) that is crucial for country innovation (Schwab, 2017, p. 12) (Fig. 1). 


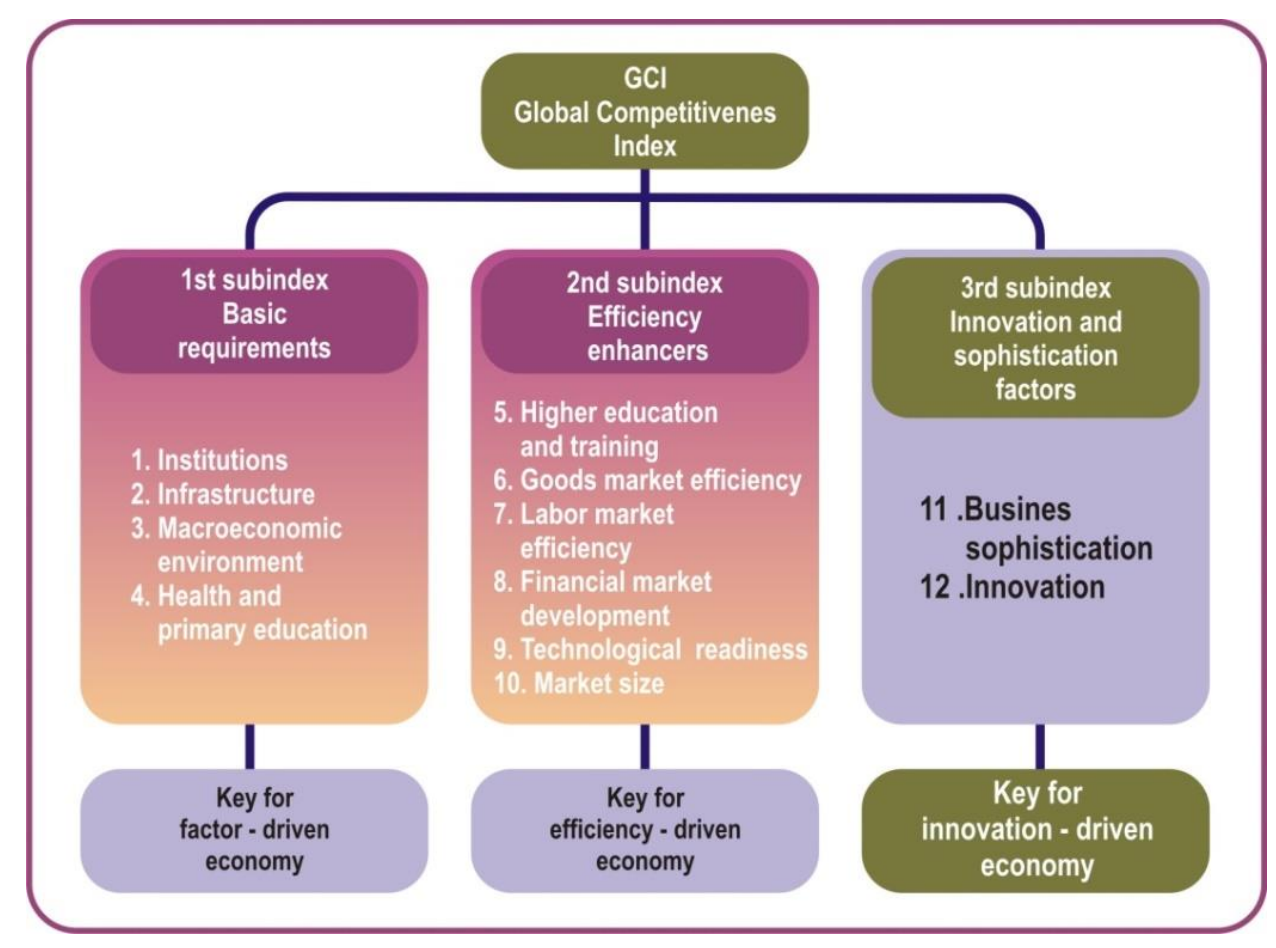

Fig. 1 GCI framework structure

Source: Schwab, 2017, p. 12

The aim of this analysis is to indicate the differences between innovative leaders and innovative learners (Despotović et al., 2016). The innovative leaders have been selected based on the latest Report of the World Economic Forum 2018, according to the $12^{\text {th }}$ pillar of the GCI (Schwab, 2018). The innovative learners are countries of Southeastern Europe. There are 10 countries in both categories. By multivariate linear regression, the influence of innovation parameters on economic development (measured by GDP per capita as a still significant indicator in economic publications) has been explored (Gligorić et al., 2018, p. 1254). Many authors, such as Savić et al. (2015) use the GII, GCI and GDPpc PPP to explore innovation as a potential for growth. Despotović et al. (2016) analyzed innovation using the $12^{\text {th }}$ pillar of GCI and their impact on GDP per capita, which was also useful for this research. In this paper, comparison was made with innovative leaders and learners. The analysis also includes the HDI, which is a wider measure and a better indicator of sustainable development, as Stiglic points out (2013). Secondary data for this level of analysis were collected from: World Economic Forum, UNCTADstat and United Nations Development Programme (UNDP) (Fig. 2). 


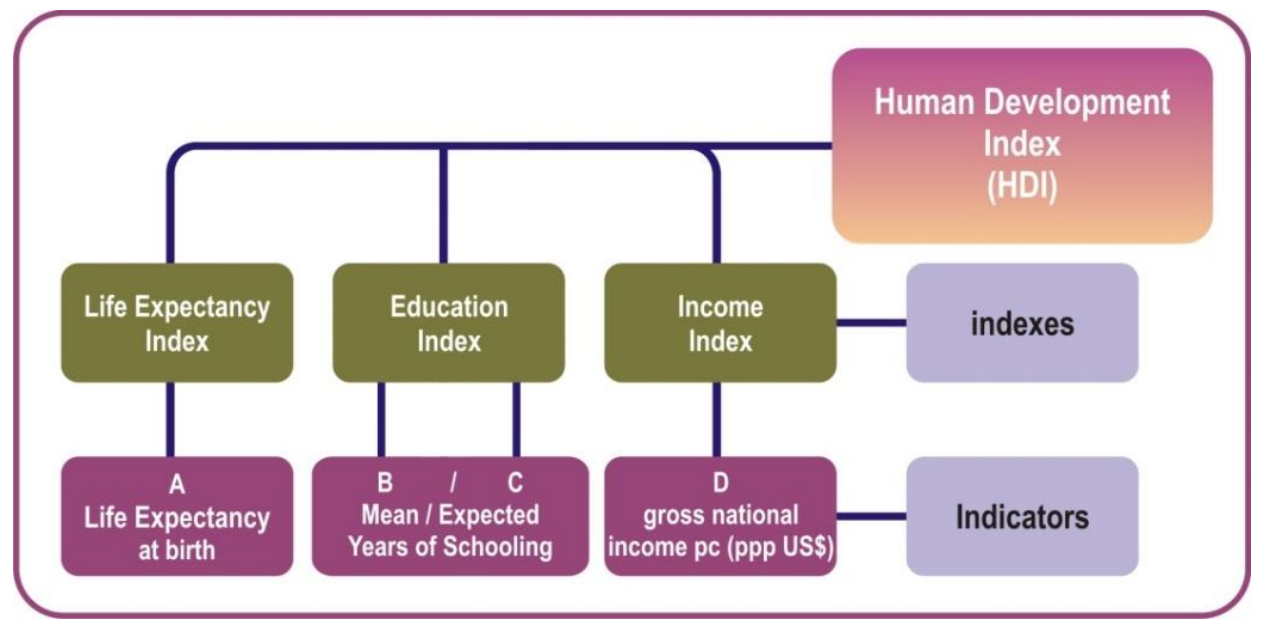

Fig. 2 HDI framework structure Source: UNDP, 2017

The second level of analysis in this paper was used to examine statistically significant differences between the observed variables, using appropriate statistical tests. Firstly, the Gross Value Added (GVA) generated by agriculture (measured as percent of GDP) is compared with the other economic activities by using data of the Statistical Office of the Republic of Serbia (National Accounts), for the period 2007-2017. Subsequently, a comparison of productivity in the agriculture of the Republic of Serbia was made in relation to other countries of Southeast Europe and the innovative leaders. The GVA of agriculture per worker was used as a measure of agricultural productivity because information technology (IT) has a direct impact on productivity in agriculture, as pointed out by Jurjević et al. (2019). This further leads to the ultimate goal, which is an increase in the profits of agricultural producers and the sustainable development of the agrarian sector.

Serbian agriculture significantly lags behind the developed European countries (Jurjević et al., 2019, p. 45), so it is very important to pay attention to the innovations of Serbian agriculture. Analysis of technological development, production and use of new technologies, efficiency of $R \& D$ systems and realization of scientific-technological policies have traditionally focused on input indicators ( $R \& D$ costs, human resources, etc.) and outcome indicators - results (patents, etc.), whose measureability is standardized and widely used, over the last decades (OECD, 2005). Despite constraints, input and output indicators (because of statistical monitoring) continue to be a significant source of information about the content and trends of technological development. The measuring of general innovation of a particular economy is limited by using only quantitative data (Kutlača\&Semenčenko, 2015). Bearing all this in mind, in this paper gross domestic expenditures for R\&D in the field of science were used as an indicator of input. For the output indicator, the inventions and patents used for the first time in practice (according to the scientific field), were used, in order to pay special attention on agricultural science. In addition, gross domestic expenditures (for R\&D by activity) were observed. Secondary data for this level of analysis were collected from Statistical Office of the Republic of Serbia - Science, Technology and Innovation - Research and Development. 


\subsection{Research Results}

\subsubsection{Cluster and Regression Analysis}

Cluster analysis ${ }^{1}$ in this paper is based on the parameters of innovation for the 20 selected countries in the period 2007-2017. In the process of grouping the hierarchical clustering method, the countries were grouped according to similarities, based on the selected parameters. The Dendogram showed that the first two clusters included 10 countries that were singled out as innovative leaders (UK, Netherlands, Germany, Taiwan, Korea, USA, Finland, Switzerland, Japan, Sweden), and in the other two were countries of Southeast Europe - SEE (Slovenia, Croatia, Greece, Romania, Bulgaria, Montenegro, Albania, Bosnia and Herzegovina, Serbia, North Macedonia). Slovenia is the only one of the SEE countries that has been completely isolated within a single cluster, which means it is the leader in innovation in SEE. Nevertheless, the differences between countries in each of the four clusters are not large. Observed by the level of separation between clusters of less than five, there is a connection between the first two clusters and the other two clusters. At the level of the difference of more than five, first two clusters of innovative leaders are merged into one and the other two clusters of countries of Southeast Europe also in one. Therefore, we get two clusters, innovative leaders and innovative learners. There is a big difference between them. That is why in the further analysis they are separately examined i.e. the impact of innovation on their economic development using multiple regression.

The assumption about the size of the sample $(\mathrm{N}>50+8 * \mathrm{~m})$ was fulfilled (Palant, $2009)$, where $m$ is the number of independent variables $(110>50+8 * 2)$.

Table 1 Importance of Innovation for Economic Development

\begin{tabular}{|c|c|c|c|c|c|c|}
\hline & \multicolumn{3}{|c|}{$\begin{array}{l}\text { Observed Countries } \\
\text { of Southeast Europe }\end{array}$} & \multicolumn{3}{|c|}{$\begin{array}{c}\text { Observed Innovative } \\
\text { Leaders Countries }\end{array}$} \\
\hline & B & $\mathrm{T}$ & Sig $(p)$ & B & $\mathrm{t}$ & $\operatorname{Sig}(p)$ \\
\hline $\begin{array}{l}\text { Innovation } \\
\text { (12th GCI) }\end{array}$ & -21.119 & -.010 & .992 & 11004.339 & 2.542 & $.012^{\text {** }}$ \\
\hline $\begin{array}{l}\text { Business Sophistication } \\
\text { (11th GCI) }\end{array}$ & 17479.17 & 7.238 & $.000^{*}$ & 28089.287 & 5.694 & $.000^{*}$ \\
\hline
\end{tabular}

In both cases (Table 1 ) is the appropriate model ( $\mathrm{p}=.000)$. In addition, the assumption of multicollinearity is satisfied, so the model is suitable for application. In the case of Southeast Europe, there is no impact of innovation on economic development, but only business sophistication as one part of the subindex of innovation and sophistication. In the case of innovative leaders, innovation and business sophistication have an impact on economic development, which suggests that innovation has a major impact on economic development. It means that more innovative countries are economically developed. On the other hand, the countries of Southeast Europe need to increase their innovation to reach higher levels of economic development. On this basis, the first hypothesis is proven.

\footnotetext{
${ }^{1}$ This research results are not tabulated for reasons of space.
} 
Table 2 Importance of Innovation for Sustainable Development

\begin{tabular}{|c|c|c|c|c|c|c|}
\hline & \multicolumn{3}{|c|}{$\begin{array}{l}\text { Observed Countries } \\
\text { of Southeast Europe }\end{array}$} & \multicolumn{3}{|c|}{$\begin{array}{c}\text { Observed Innovative } \\
\text { Leaders Countries }\end{array}$} \\
\hline & B & $\mathrm{t}$ & Sig (p) & B & $\mathrm{t}$ & Sig (p) \\
\hline $\begin{array}{l}\text { Innovation } \\
\text { (12th GCI) }\end{array}$ & .051 & 3.864 & $.000^{*}$ & .012 & 2.260 & $.026^{* *}$ \\
\hline $\begin{array}{l}\text { Business Sophistication } \\
\text { (11th GCI) }\end{array}$ & .072 & 5.033 & $.000^{*}$ & .015 & 2.220 & $.029^{* * *}$ \\
\hline
\end{tabular}

In both cases (Table 2$)$ is the appropriate model $(\mathrm{p}=.000)$. In addition, the assumption of multicollinearity is satisfied. Innovation has a full impact on sustainable development, both in the case of the countries of Southeast Europe, as well as in the countries of innovative leaders (here Taiwan is omitted from the sample, because of the undisclosed HDI data from China). This means that the importance of innovation is even greater for sustainable development, where sustainable development is a broader concept than economic development (Stiglic, 2013, p. 316).

Innovation and business sophistication can be combined into one factor, and by simple linear regression their impact on economic and sustainable development can be examined.

Table 3 Factor of Innovation and Sophistication $\left(3^{\text {rd }}\right.$ subindex of GCI)

\begin{tabular}{|c|c|c|c|c|c|c|}
\hline & \multicolumn{3}{|c|}{$\begin{array}{l}\text { Economic Growth } \\
\text { (GDP per capita) }\end{array}$} & \multicolumn{3}{|c|}{$\begin{array}{c}\text { Sustainable Development } \\
\text { (HDI) }\end{array}$} \\
\hline & B & $\mathrm{T}$ & Sig (p) & B & $\mathrm{T}$ & Sig (p) \\
\hline $\begin{array}{l}\text { Observed Countries of } \\
\text { Southeast Europe }\end{array}$ & 16613.160 & 10.635 & $.000^{*}$ & .122 & 13.896 & $.000^{*}$ \\
\hline $\begin{array}{l}\text { Observed Innovative } \\
\text { Leaders Countries }\end{array}$ & 37703.582 & 9.017 & $.000 *$ & .027 & 4.935 & $.000^{*}$ \\
\hline
\end{tabular}

In both cases in the Table 3 is the appropriate model $(\mathrm{p}=.000)$. The factor of innovation and sophistication has an impact on the economic and sustainable development of the observed countries.

\subsubsection{Statistical Tests}

For the second level of analysis, Kolmogorov-Smirnov and Shapiro-Wilk tests for the distribution normality found that no indicators have a normal distribution, so nonparametric techniques are needed.

Kruskal-Wallis test was used to determine the contribution of agriculture to the economic development of the Republic of Serbia in relation to other economic activities, as well as the state of Serbian agriculture in relation to the countries of Southeast Europe and the economically developed countries. 
Table 4 Importance of Agriculture for Economic Development and Agricultural Productivity

\begin{tabular}{|c|c|c|c|}
\hline GVA & \multicolumn{3}{|c|}{ Agriculture Value Added per worker } \\
\hline Chi-Square & & 201.099 & \\
\hline Asymp. Sig. (p) & & $\mathrm{p}=.000^{*}$ & \\
\hline Economic Activities & $\begin{array}{c}\text { Mean } \\
\text { rank }\end{array}$ & Country & $\begin{array}{c}\text { Mean } \\
\text { rank }\end{array}$ \\
\hline Agriculture & 194.45 & Serbia & 32.45 \\
\hline Mining & 62.86 & Montenegro & 125.55 \\
\hline Manufacturing Industry & 226.00 & North Macedonia & 50.91 \\
\hline Electricity, Gas and Steam Supply & 111.68 & Albania & 15.82 \\
\hline Water Supply & 50.86 & $\mathrm{~B} \& \mathrm{H}$ & 32.91 \\
\hline Construction & 155.14 & Croatia & 75.64 \\
\hline Trade & 210.95 & Bulgaria & 66.09 \\
\hline Traffic & 164.27 & Romania & 9.36 \\
\hline Accommodation Services and Meals & 43.00 & Slovenia & 77.36 \\
\hline Information and Communication & 158.23 & Greece & 100.18 \\
\hline Financial Activities & 99.59 & Germany & 147.09 \\
\hline Real Estate Business & 206.59 & USA & 196.80 \\
\hline Professional, Scientific, Innovation and Technical Activities & 124.23 & Switzerland & 130.27 \\
\hline Administrative and Support Service Activities & 78.82 & Sweden & 188.82 \\
\hline State Administration & 123.14 & Japan & 123.30 \\
\hline Education & 131.09 & UK & 160.36 \\
\hline Health and Social Protection & 174.64 & Korea & 95.55 \\
\hline Art, Entertainment and Recreation & 40.05 & Netherlands & 185.00 \\
\hline Other Service Activities & 57.41 & Finland & 172.73 \\
\hline Activity of the Household as an employer & 17.00 & & \\
\hline The Activity of Extraterritorial Organizations and Bodies & 6.00 & & \\
\hline
\end{tabular}

In the observed period 2007-2017, it is visible that agriculture has a significant impact on the economic development in the Republic of Serbia (Table 4). From the economic activities classified in the 21 group, agriculture is on the $4^{\text {th }}$ place, behind the manufacturing industry, trade and real estate business. On the other hand, productivity in the agriculture of the Republic of Serbia not only lags behind the more developed countries, but also behind many countries of Southeast Europe. Behind Serbia are only Albania and Romania. Because of the fact that agriculture contributes significantly to the economic development of Serbia, productivity should be increased primarily in agriculture by introducing new technologies and innovations, because they have direct impact on productivity in agriculture (Jurjević et al., 2019). This proves the second hypothesis of this paper.

Simple linear regression has determined that gross domestic expenditure on R\&D has an impact on inventions and patents that were firstly used in practice (Table 5), according to the scientific field $(\mathrm{p}=.000)$, which means that more should be invested in agricultural science. Kruskal-Wallis test was used to determine the ratio of investments in agricultural science in relation to other sciences in the Republic of Serbia, in terms of an indicator distribution that is not normal.

In the observed period (2007-2017) investing in R\&D in Agricultural Sciences (Table 5) was behind the Natural, Engineering and Social Sciences, and in front of Medical and Humanistic Sciences. Agricultural Sciences according to inventions and patents have 
surpassed Social Sciences, from which it is concluded that Agricultural Science has achieved better results than the level investment for R\&D.

Table 5 Research and Development Vs Inventions and Patents (according to the Scientific Fields in the Republic of Serbia)

\begin{tabular}{lcc}
\hline & Research \& Development & Inventions and Patents \\
\hline Chi-Square & 46.520 & 36.012 \\
Asymp. Sig. (p) & $.000^{*}$ & $.000^{*}$ \\
\hline Scientific Fields & Mean rank & Mean rank \\
\hline Natural Sciences & 51.64 & 37.59 \\
Engineering Technology & 53.95 & 58.50 \\
Medical Sciences and Health Sciences & 18.91 & 31.09 \\
Agricultural Science & 20.68 & 35.64 \\
Social Science & 37.73 & 24.18 \\
Humanities & 13.30 & 14.00 \\
\hline
\end{tabular}

Note: The value is significant at $\left.1 \%\left({ }^{*}\right), 5 \%()^{*}\right)$, and $10 \%\left({ }^{* * * *}\right)$ confidence level

Source: Authors' research

The Kruskal-Wallis test found that the gross domestic R\&D expenditures by activities, ranging from 71 business activities, places agriculture on the $34^{\text {th }}$ place $(p=.000)^{2}$. This is also insufficient because agriculture is of great importance for the economic development of the Republic of Serbia. Namely, more resources should be invested for R\&D in agriculture, as well as in Agricultural Science, especially for the launch of innovations.

The analysis of business subjects according to innovations and business sectors is also very important for the Republic of Serbia.

Table 6 Business subjects towards innovation and sectors of activity in the Republic of Serbia

\begin{tabular}{|c|c|}
\hline \multicolumn{2}{|l|}{ Business subjects } \\
\hline Chi-Square & \\
\hline Asymp. Sig. (p) & \\
\hline Business Sectors & Mean rank \\
\hline Agriculture, Forestry and Fisheries & 24.25 \\
\hline Mining & 18.63 \\
\hline Manufacturing Industry & 49.38 \\
\hline Supply of Electricity, Gas and Steam & 48.88 \\
\hline Water Supply and Wastewater Management & 19.75 \\
\hline Construction & 25.88 \\
\hline Wholesale and Retail Trade and Repair of Motor Vehicles & 32.63 \\
\hline Traffic and Storage & 21.25 \\
\hline Accommodation Services and Meals & 30.50 \\
\hline Information and Communication & 48.38 \\
\hline Financial Activities and Insurance & 42.50 \\
\hline Real Estate Business & 10.25 \\
\hline Professional, Scientific, Innovation and Technical Activities & 43.88 \\
\hline Administrative and Support Service Activities & 38.88 \\
\hline Health and Social Protection & 22.17 \\
\hline Art, Entertainment and Recreation & 22.17 \\
\hline
\end{tabular}
Note: The value is significant at $1 \%\left(^{*}\right), 5 \%\left(^{*}\right)$, and $10 \%\left({ }^{* * * *}\right)$ confidence level Source: Authors' research

\footnotetext{
${ }^{2}$ This research results are not tabulated for reasons of space.
} 
Businesses subjects according to innovation in agriculture are on the $10^{\text {th }}$ place in comparation with the other sectors (total 16), and it is again insufficient because agriculture is at the top in terms of contribution to economic development.

\section{CONCLUSION}

In addition to the impact on economic development, innovation has an even more pronounced impact on sustainable development. The influence of innovation on economic development in the innovator countries is visible, and it makes them economically developed countries, unlike the countries of Southeast Europe. This proves the first hypothesis that more innovative countries are the economically developed ones.

Given that the influence of innovation on the economic development in the countries of Southeast Europe is missing, where only Slovenia is distinguished as an innovative leader, the economic lagging of these countries behind more innovative and at the same time economically developed countries is visible. It is necessary to approach this problem carefully, to stop in the long term even greater lag and negative reflection on sustainable development.

For the future research, it is important to analyze how to increase the innovation of Southeast Europe, and analyze all elements of the $12^{\text {th }}$ Pillar of GCI as well as GII, and their impact on economic and the sustainable development of different countries. The analysis should include the relationship between R\&D costs, the inventions and patents of the chosen countries, as well as their comparison with economically developed countries.

Agriculture in the Republic of Serbia has many natural resources and significant contributon to GDP, employment and exports. Namely, agriculture is one of the key economic activities for the Serbian economy, but it is lagging behind in terms of productivity. In addition, there is insufficient investment in agriculture and R\&D in agricultural sciences. Thereby, agricultural businesses lag far behind other sectors of the economy in terms of innovation. Considering that many authors emphasize the great importance of introducing modern technologies for increasing productivity in agriculture, it could be concluded that insufficient innovation is one of the important causes of the lagging of agricultural productivity in the Republic of Serbia, not only behind more developed countries, but also behind many countries in the region. Therefore, it is important to introduce innovations in agricultural production process. It could have a very positive impact on productivity growth and sustainable development of the agri-food sector, which is of great importance for economic development of the Republic of Serbia. Accordingly, innovations are very important factors for the future development of agriculture in the Republic of Serbia. This conclusion proves the second hypothesis of this paper and it requires higher investments in agricultural $\mathrm{R} \& \mathrm{D}$, as well as other accompanying efforts at macro and micro levels.

Acknowledgement: The paper is a part of the research done within the project number III 47005, financed by the Ministry of Education, Science and Technological Development of the Republic of Serbia. 


\section{REFERENCES}

Ančić, J., Laketa, M. \& Laketa, L. (2014). Uloga poreske politike u ekonomskom razvoju Srbije [The role of tax policy in the economic development of Serbia]. Casopis za ekonomiju i tržišne komunikacije, 4 (2), 306-319. doi: 10.7251/EMC1402306A

Bošnjak, M. (2005a). Koncepcija razvoja inovativne privrede i društva u Republici Srbiji [The concept of innovative development of economy and society in the Republic of Serbia]. U: Matejić, V. (ur.), Tehnologija, kultura i razvoj (pp.30-48). Subotica: Udruženje „Tehnologija i društvo“.

Bošnjak, M. (2005b). Konkurentnost i razvoj kao poluge evropske perspektive Srbije [Competitiveness and Development as Levers of Serbia's European Perspective]. Economic annals, 50 (166), 129-148. https://doi.org/10.2298/EKA0566129B

Ceballos, G., Ehrlich, P., Soberón, J., Salazar, I. \& Fay, J.P. (2005). Global mammal conservation: what must we manage?. Science, 309 (5734), 603-607. doi: 10.1126/science.1114015

Dajić, M. (2017).Uloga i značaj inovacija u razvoju privrede Srbije. Ekonomski signali, 12 (1), 55-64. doi:10.5937/ekonsig1701055D

Despotović, D., Cvetanović, S. \& Nedić, V. (2014). Innovativeness and competitiveness of the Western Balkan countries and selected EU member states. Industrija, 42 (1), 27-45. doi: 10.5937/industrija42-4602

Despotović, D., Cvetanović, S. \& Nedić, V. (2016). Analysis of innovativeness, as a determinant of competitiveness of the selected European countries. Industrija, 44 (1), 89-111. doi: 10.5937/industrija1-9365

European Commision (2018). European Innovation Scoreboard-Serbia, Retrieved from: file:///H:/inovativnost/ Serbia.pdf, Accessed on: 23 April 2019.

Gault, F. (2018). Defining and measuring innovation in all sectors of the economy. Research policy, 47 (3), 617-622. doi:10.1016/j.respol.2018.01.007

Giddings, B., Hopwood, B. \& O’Brien, G. (2002). Environment, Economy and Society: Fitting the Together into Sustainable Development. Sustainable Development, 10, 187-196. https://doi.org/10.1002/sd.199

Gligorić, M., Jovanović Gavrilović, B. \& Savić, Lj. (2018). Prosperity index as a measure of wellbeing in European Union and Western Balkan countries. Teme, 42 (4), 1253-1275. doi: 10.22190/TEME1804253G

Global Footprint Network (2018). National Footprint Accounts 2018 edition, Retrived from: https://data.footprintnetwork.org/\#/countryTrends?cn=272\&type=BCpc,EFCpc

http://www3.weforum.org/docs/GCR2018/05FullReport/TheGlobalCompetitivenessReport2018.pdf, Accessed on: 12 May 2019.

Jakopin, E. (2011). The Framework of New Serbian Industrial Policy. Ekonomika preduzeća, 59 (1-2), 73-88. doi:10.5937/ekopre1102073J

Jurjević, Ž., Bogićević, I., Đokić, D. \& Matkovski, B. (2019). Information technology as a factor of sustainable development of Serbian agriculture. Strategic management, 24 (1), 41-46. doi:10.5937/StraMan1901041J

Krstić, M., Krstić, B. \& Antonović, R. (2019).The Importance of Science for Improving Competitiveness of National Economy. Facta Universitatis, Series: Economics and Organization, 16 (1), 13-30. https://doi.org/10.22190/FUEO1901013K

Kutlača, Đ. \& Semenčenko, D. (2015). Nacionalni inovacioni sistem u Srbiji: prošlost, sadašnjost, budućnost [The national innovation system in Serbia: Past, Present, and Future]. U okviru projekta Istraživanje i razvoj platforme za naučnu podršku u odlučivanju i upravljanju naučnim i tehnološkim razvojem u Srbiji. Beograd: Institut „Mihajlo Pupin“, Retrived from: http://www.pupin.rs/cirnt/wp-content/uploads/2012/12/ NIS2-P1-color.pdf, Accessed on: 20 May 2019.

Kvrgić, G. \& Ristić, L. (2018). Unutrašnji izazovi održivog razvoja ruralnih područja Republike Srbije [Internal challenges of sustainable development of rural areas of the Republic of Serbia.]. Naučne publikacije Državnog univerziteta u Novom Pazaru, Serija B: Društvene i humanističke nauke, 1 (1), 28-46.

Miltojević, B. (2011). Kultura kao dimenzija održivog razvoja [Culture as a dimension of sustainable development]. Teme, 35 (2), 639-653.

Moran, D., Wackernagel, M., Kityes, J., Goldfinger, S. \& Boutaud, A. (2008). Measuring sustainable development Nation by nation. Ecological Economics, 64 (3), 470-474. https://doi.org/10.1016/j.ecolecon. 2007.08.017

OECD (2005). Guidelines for collecting and interpreting innovation data. The Measurement of Scientific and Technological Activities. Paris:OECD Publishing.

Palant, Dž. (2009). SPSS: Priručnik za preživljavanje [SPSS: Survival Manual]. Beograd: Mikro knjiga.

Porter, M. (2008). O konkurenciji [About the Competition]. Beograd: Fakultet za ekonomiju, finansije i administraciju.

Praća, P., Paspalj, M. \& Paspalj, D. (2017). Ekonomska analiza uticaja savremene poljoprivrede na održivi razvoj [The economic analysis of the impact of modern agriculture on sustainable development]. Časopis za menadžment, pravo i finansije, 3 (1), 37-51. doi:10.5937/Oditor1701037P 
Radošević, S. (2004). A Two-Tier or Multi-Tier Europe? Assessing the Innovation Capacities of Central and East European Countries in the Enlarged EU. Journal of Common Market Studies, 42 (3), 641-666. https://doi.org/10.1111/j.0021-9886.2004.00522.x

Ristić, L. (2016). Spoljni izazovi razvoja agrara Republike Srbije [External challenges of agricultural development of the Republic of Serbia]. U: V. Leković (ur.), Institucionalne promene kao determinanta privrednog razvoja Republike Srbije (pp. 211-229). Kragujevac: Ekonomski fakultet Univerziteta u Kragujevcu.

Savić, N., Pitić, G. \& Trbovich, A. (2015). Innovation and Creative Industries as a basis for Serbian Reindustrialisation. Ekonomika preduzé́a, 63 (1-2), 67-81.

Schwab, K. (2017). The Global Competitiveness Report 2017-2018. Geneva: World Economic Forum, Retrieved from: http://www3.weforum.org/docs/GCR20172018/05FullReport/TheGlobalCompetitiveness Report2017-2018.pdf, Accessed on: 02 June2019.

Schwab, K. (2018). The Global Competitiveness Report 2018. Geneva: World Economic Forum, Retrieved from: http://www3.weforum.org/docs/GCR2018/05FullReport/TheGlobalCompetitivenessReport2018.pdf, Accessed on: 02 June2019.

Stiglic, J. (2013). Slobodan pad. Novi Sad: Akademska knjiga.

Legatum Institute (2018). The Legatum Prosperity Index, Retrieved from: https://www.prosperity.com/rankings, Accessed on: 02 June 2019.

UNDP (2005). Human development report 2005. New York: United Nations Development Programme, Retrieved from: http://hdr.undp.org/sites/default/files/reports/266/hdr05_complete.pdf, Accessed on: 05 June 2019.

UNDP (2017). Human Development Index. New York: United Nations Development Programme, Retrieved from: http://hdr.undp.org/en/content/human-development-index-hdi, Accessed on: 04 August 2017.

Van der Veen, M. (2010). Agricultural innovation: invention and adoption or change and adaptation?. World Archaeology, 42 (1), 1-12.doi:10.1080/00438240903429649

Wackernagel, M., Monfreda, C., Moran, D., Wermer, P., Goldfinger, S., Deumling, D. \& Murray, M. (2005). National footprint and biocapacity accounts 2005: The underlying calculation method. Oakland, CA: Global Footprint Network, Retrieved from: http://citeseerx.ist.psu.edu/viewdoc/download?doi=10.1.1. 495.5633\&rep=rep1\&type=pdf, Accessed on: 07 June 2019

Wackernagel, M., Schulz, B., Deumling, D., Callejas Linares, A., Jenkins, M., Kapos, V., Monfreda, C., Loh, J., Myers, N., Norgaard, R. \& Randers, J. (2002). Tracking the ecological overshoot of the human economy. Proceedings of the National Academy of Sciences of the United States of America, 99 (14), 9266-9271.

WIPO (2018a). The global innovation index 2018: energizing the world with innovation, Retrieved from: https://www.wipo.int/edocs/pubdocs/en/wipo_pub_gii_2018-chapter1.pdf, Accessed on: 25 Aprl 2019.

WIPO (2018b). Global Innovation Index 2018 - Serbia, Retrieved from: https://www.wipo.int/edocs/ pubdocs/en/wipo_pub_gii_2018-profile41.pdf, Accessed on: 25 Aprl 2019.

World Economic Forum (2013). The Global Competitiveness Report 2013-2014, Retrieved from: http://www3. weforum.org/docs/WEF_GlobalCompetitivenessReport_2013-14.pdf, Accessed on: 28 May 2019.

\section{ZNAČAJ INOVATIVNOSTI ZA ODRŽIVI RAZVOJ PRIVREDE I POLJOPRIVREDE U REPUBLICI SRBIJI}

$S$ obzirom da nije dovoljno samo ostvariti ekonomski razvoj, već održivi razvoj u dužem vremenskom periodu, neophodno je težiti inovativnosti, koja je izuzetno važan faktor ekonomskog rasta i održivog razvoja. Pritom je posebno važno inovirati one privredne delatnosti koje su ključne za privredni razvoj $i$ gde postoje komparativne prednosti. U skladu sa navedenim, cilj ovog rada jeste dokazati da su inovacije ključ uspeha i ostvarivanja održivog razvoja. Klaster analizom su izdvojeni tzv. inovativni lideri $i$ učenici. Republika Srbija je prikazana kao zemlja gde je poljoprivreda jedna od značajnih privrednih delatnosti. I pored toga, po produktivnosti u poljoprivredi ne samo da zaostaje za inovativnim liderima, već $i$ za drugim zemljama Jugoistične Evrope koje su se izdvojile kao inovativni učenici. Takođe, po inovativnosti u poljoprivredi značajno zaostaje $i$ za drugim privrednim delatnostima na nacionalnom nivou, zbog čega bi posebnu pažnju trebalo posvetiti ovom pitanju.

Ključne reči: inovativnost, produktivnost, održivi razvoj, privredni razvoj, poljoprivreda. 